\title{
Legal Renewing of Consumer Protection (Himâyah al-Mustahlaki) Through Islamic Law Perspective
}

\author{
Burhanuddin Susamto ${ }^{1} \&$ Ros Amira binti Mohd Ruslan ${ }^{2}$
}

\begin{abstract}
Legal Renewing of Consumer Protection (Himâyah al-Mustahlaki) Through Islamic Law Perspective. The purpose of this paper is to offer the concept of reforming consumer protection law (himâyah al-mustablaki) through the perspective of Islamic law. To achieve this goal the author uses the integration of science as a method of analyzing from normative legal research by combining the statute and conceptual approaches. Although in the shari'a does not mention the term consumer directly, it contains principles that if carried out by business actors can provide protection to consumers. The potential loss inherent in consumers is generally divided into two, namely (1) Material losses (al-khasârah al-mâdiyah) both in the form of financial and non-financial assets; and (2) Humanity loss (al-khasârah al-insâniyah) both in the form of body and spirit. The overall potential loss needs to be accommodated in an integrated legislation to better guarantee legal certainty for consumers. The implementation of consumer protection can be realized through preventive treatment through fostering awareness of business actors or repressive treatment through the1 enforcement of legal sanctions.
\end{abstract}

Keyword: law, protection, consumer, Islam

Abstrak: Pembaruan Hukum Tentang Perlindingan Konsumen (Himâyah alMustahlaki) dalam Perspektif Hukum Islam. Tujuan penulisan ini adalah untuk menawarkan konsep pembaharuan hukum perlindungan konsumen (bimâyah almustahlaki) melalui perspektif hukum Islam. Untuk mencapai tujuan tersebut penulis menggunakan metode analisis integrasi ilmu pengetahuan dari penelitian hukum normatif dengan memadukan antara pendekatan perundang-udangan dan konseptual. Dalam syariat meskipun tidak menyebut secara langsung istilah konsumen, namun memuat prinsip-prinsip yang apabila dijalankan oleh pelaku usaha dapat memberikan perlindungan terhadap konsumen. Potensi kerugian yang melekat pada konsumen secara umum terbagi menjadi dua yaitu (1) Kerugian yang bersifat kebendaan (al-khasârah al-mâdiyah) baik berbentuk aset finansial maupun non finansial; dan (2) kerugian yang bersifat insaniyah (al-khasârah al-insâniyah) baik berbentuk jasmani maupun ruhani. Keseluruhan potensi kerugian tersebut perlu diakomodasi dalam suatu peraturan perundang-undangan yang terintegrasi untuk lebih menjamin kepastian hukum bagi konsumen. Implementasi perlindungan konsumen dapat diwujudkan melalui upaya preventif melalui pembinaan kesadaran pelaku usaha maupun represif melalui pemberlakuan sanksi hukum.

Kata Kunci: hukum, perlindungan, konsumen, Islam

\footnotetext{
${ }^{1}$ Sharia Faculty, State Islamic University Maulana Malik Ibrahim, Malang, Indonesia. Gedung Megawati Soekarno Putri, Jl. Gajayana 50, Malang, Kode Pos 65144, Indonesia

${ }^{2}$ Academy of Contemporary Islamic Studies (ACIS) UiTM Melaka, 40450 Shah Alam, Selangor, Malaysia

E-mail: ${ }^{1}$ burhanuddin@syariah.uin-malang.ac.id, ${ }^{2}$ rosamira@uitm.edu.my
} 


\section{Introduction}

Humans are created by Allah SWT in a state of natural (fitrah) through a combination of physical elements (QS.Ali-Imran [3]: 59) (QS.As-Sajdah [32]: 7) and spirituality (QS.Al-Hijr [15]: 29 ) (QS.AsSajdah [32]: 9). From these two elements of human creation, they are transformed into necessities of life that must be fulfilled, such as food, clothing, housing, etc. (QS. Thaha [20]: 118-119). Spiritual needs can be fundamentally fulfilled through obedience to Allah, which among others is by consuming foods and drink that are halâl both in terms of their substances ( halâl li dzâtihi) and in terms of non substances (balâl li ghairihi). Therefore to meet their needs adequately, humans need to establish relationships with other people to transaction legally. In a transaction there are those who act as business actors (producers, distributors/sellers) and some act as consumers. Therefore, consumers as user of goods and/services need to be guaranteed legal protection.

The economic development of a country is largely determined by success in the real sector. The faster growth of the real sector, the faster economic growth of a country, said so that because the availability of goods or services to fullfil consumer needs is increasing. To achieve successful development in the real sector, economic empowerment activity is needed by involving various business actors. According to the consumer protection law, business actor is any individual or business company, either in the form of a statutory body or otherwise, set up and domiciled or undertaking activities in the jurisdiction of the state of the Republic of Indonesia, both individually and jointly through agreements on the running of business activities in various economic areas. ${ }^{1}$ The fact that there are business actors who act as the producers of products, distributors and some who are becoming traders to sell products to consumers.

Consumers use a product to meet their need, namely primary, secondary and even tertiary needs. A good product is a product that

${ }^{1}$ Article 1 Poin 4 Law of Republic Indonesia Number 8 Year 1999 concerning Customer Protection. 
is halâl and quality with the price is affordable so that it can provide maximum benefits for its cunsumers. The consumers have potential losses in buying a product, so they need the legal protection. The general reason why protection need to be given to the consumers is related to their existence who always on a weak position. There are several factors that can be used as indicators of the weak position of consumers if they are compared to the position of business actors, namely: (1) The high level of consumer dependence on a product; (2) The weak knowledge about the production process; and (3) The weak bargaining power of customers. ${ }^{2}$ Although the decision to buy is in the hands of consumers, but because of their dependence on a product that causes consumers to accept purchases to fullfil their needs. The fact that not all needs can be done by consumers because their knowledge and ability is limited. Even there are some products the manufacturing process is kept secret and protected by intellectual property rights. The factor of dependency and limited knowledge for manufacturing product that cause consumer bargaining to be weak so often used by business actors to get unilateral profits.

The purchases of products by consumers can be done by face to face transaction directly or through online transaction media. Direct transactions can make it easy for consumers to access the quality of products they will purchase, so that their rights are more protected than online transactions. In the age of information scattered in cyberspace, there is still no guarantee that the information will make consumers more well-informed or that the relevant information reaches the consumers. ${ }^{3}$ Mancuso argued that the success of the electronic transaction using internet is based on the opportunity for consumer to approach a wide range of offer without the constraint of business hours, the ease of comparing simultaneously different sites which offer identical or interchangeable service, and also the opportunity to survey and find

\footnotetext{
${ }^{2}$ Burhanuddin S, Pemikiran Hukum Perlindungan Konsumen dan Sertifikasi Halal (Malang: UIN Maliki Press, 2011), p. 6.

${ }^{3}$ Shidarta Shidarta and Stefan Koos, 'Introduction To A Social-Functional Approach In The Indonesian Consumer Protection Law', Veritas et Justitia, 5.1 (2019), 49-79 (p. 57) <https:// doi.org/10.25123/vej.3292>.
} 
adequate information to make a satisfactory choise without direct relations with sales representatives. ${ }^{4}$ It means that without the opportunity to survey, to chooise, and to get adequate information, the online transacton has the potential to harm consumer.

The position of consumers as a weak party also recognizes internationally as reflected in the resolution of the UN General Assembly, Number A/RES/39/248 Year 1985 concerning Guidelines for Consumers Protection, states that: "Taking into account of interests and needs of consumers in all countries, particularly those in developing counties, recognizing that consumers often face imbalances in the economics terms, educational levels, and bargaining power, and bargaining in the mind that consumers should have the right of access to non-hazardous product, as well as the right to promote just, equitable and sustainable economic and social development." "The position of consumers who are weak in the presence of business actors raises the idea of the need for a regulation that is in favor of the consumers interests.

The first aspect of consumer protection efforts is the enactment of regulations on the importance of producers responsibility for the possibility of consumer losses arising from the using their products. The producer responsibility for consumer safety due to the use of goods and / or services produced is called product liability. Product liability in the consumer protection law is not new. Products are generally interpreted as goods which can be seen, held (tangible goods), both movable and immovable. However, related to the issue of consumer protection, product liability is not only interpreted as tangible goods but also includes intangible goods such as the provision of service products. The demands

${ }^{4}$ S. Mancuso, 'Consumer Protection In E-Commerce Transaction: A First Comparasion Between European Law and Islamic Law', Journal of International Commercial Law and Technology, 2 (2007), 1 (P. 1); The Impersonality of E-Commerce Weakens the Relationship Between Businesses and Consumers, Thereby Increasing Consumer Vulnerability That Could Lead To Unfair Commercial Practices and Causing Uncertainty and Lack of Trust By Consumers. See Sinta Dewi Rosadi And Zahra Tahira, 'Consumer Protection In Digital Economy Era : Law In Indonesia', Yustisia Jurnal Hukum, 7.1 (2018), 85-97 (p. 1) <https://doi.org/10.20961/yustisia. v0i0.20144>.

${ }^{5}$ Resolution of the UN General Assembly, Number A/RES/39/248 Year 1985 Concerning Guidelines for Consumers Protection. 
of product liability from business actors are basically justified if they have fulfilled several elements, namely: (a) The occurrence of defaults or violations committed by business actors; (b) There is an element of loss experienced by consumers; and (c) There is an element of a causal relationship between defaults and unlawful acts with the reality of losses suffered by consumers. ${ }^{6}$

Consumptions of products in the form of substances (material) are by eating and drinking or just taking benefits of the substance. The risk of eating and drinking a product that is harâm and dangerous in terms of its substance not only have an impact on material losses, but also have an impact in humanity losses etiher physical or spiritual. The risk of taking the benefits of goods which have no quality from the results of the purchase is only affects material losses. The products in the form of services are non-material, so the way to consume them is only taking the benefits of them. The risk of consuming services that are not in accordance with human nature (fitrah) can result in spiritual damage. The fact that the implementation of consumer protection laws due to consuming services that are harmful to the human soul has not received much attention. Consumer protection law that already exists today according to the author needs to be reconstructed so that it can coverage more comprehensive, which includes all forms of consumer potential losses. Therefore research on the legal concept of consumer protection in an Islamic perspective is a necessity to be used as input for renewing consumer protection regulations in Indonesia.

\section{Research Methodology}

The writing of this article is the result of normative legal research, namely research that makes legal texts an object of study. The meaning of legal texts here are the norms of regulation and values of Islamic laws relating to consumer protection. In Islamic law there are any values which can be explored directly from the sources of sharia (al-qur'ân

\footnotetext{
${ }^{6}$ Burhanuddin S, Pemikiran Hukum Perlindungan Konsumen dan Sertifikasi Halal, p. 7.
} 
and al-hadith) or from the results of the explanations of the scholars found in the books of fiqh and other scientific works that explain theory of consumer protection. If the object of discussion is in the form of consumer protection regulation as a formal law, the approach used is the statute approach. If the object of discussion is in the form Islamic law as a informal law and other theoris related, the approach used is the conceptual approach. Legal material that has been collected, then will be analyzed using the method of integration of science to harmonize the facts of consumer protection theoris and its regulations that has been applied to the values of Islamic law, so resulting in a more perfect legal concept.

\section{General Theory of Consumer Protection}

Consumer protection ${ }^{7}$ is a term used to describe the existence of a law that provides protection to consumers from losses for the use of goods and / or services. According to legislation, consumer protection is all efforts that ensure legal certainty to provide protection to consumers. ${ }^{8}$ The mean of consumer is anybody using goods and/or services which are available in the community, both for his own purpose, for the purpose of his family and other people as well as other living creatures and which are not to be traded. ${ }^{9}$ According to the author, what consumers mean is the human using of goods and / or service products that aim to fulfill various needs for supporting survival to

${ }^{7}$ Formally, consumer protection in Indonesia is regulated under Law Number 8 Year 1999 on Consumer Protection. The objectives of consumer protection law are for to enhance the integrities and values of the consumers by avoiding negative excess of using the goods and/ or services. Martin Roestamy, 'Consumer Protection of Halal Meat under Islamic Law and Indonesian Regulation', Journal of Law, Policy and Globalization, 35.0 (2015), 88-94-94 (p. 90); Beside that, consumer protection also was regulated under Law Number 33 Year 2014 on Halal Product Insurance. But the weakness of the regulation lies on the general criminal sanction without any specific minimum provision 'Juridical Analysis on Consumer Protection in Safe and Halal Food Distribution | Wiryani | Jurnal Dinamika Hukum', p. 1 <http://dinamikahukum. fh.unsoed.ac.id/index.php/JDH/article/view/1586>.

${ }^{8}$ Article 1 Poin 1 Law of Republic Indonesia Number 8 Year 1999 concerning Customer Protection

${ }^{9}$ Article 1 Poin 2 Law of Republic Indonesia Number 8 Year 1999 concerning Customer Protection 
worship God. Based on that definitions, it can be understood that the purpose of consuming products which is in accordance with natural needs (fitrah) is only to support sustainability life. While the purpose of life itself is to worship God.

The law has divided consumers into: (1) Intermediate consumers (konsumen antara), namely consumers who use a product as part of the next production process; and (2) Final consumers (konsumen akhir), namely consumers who use a product to consume themselves. ${ }^{10} \mathrm{Of}$ the two divisions, meaning the term consumer can be interpreted broadly, namely all users of goods and/or services for certain purposes. Whereas according to the law, term consumer is interpreted only the last user of goods and/or services to fullfil needs. ${ }^{11}$ Therefore limiting the definition of consumers only in the scope of the final consumer without including intermediate consumers causes the protection efforts to be uneven. ${ }^{12}$ It means that the law has not provided legal certainty to protect intermediate consumers who buy raw materials for next production.

Basically, the relationship between business actors and consumers is always based on an agreement. The agreement which is made legally apply parties laws for the parties who made them. The legal consequences of an agreement are the emergence of rights and obligations that must be fulfilled by each party. It means that each party other than have authority for their rights, they are responsible for fulfilling their obligations to avoid legal sanctions. In the consumer protection law, the rights and obligations betwen business actors and consumers are stated proportionally as follows:

${ }^{10}$ Explanation Article 1 Poin 2 Law of Republic Indonesia Number 8 Year 1999 concerning Customer Protection

${ }^{11}$ Explanation Article 1 Poin 2

12 Shidarta, Hukum Perlindungan Konsumen (Jakarta: Grasindo, 2000), pp. 4-5; Az. Nasution, Hukum Perlindungan Konsumen (Jakarta: Dayawidya, 1999), pp. 10-16. 


\section{The Business Actors}

Rights

Obligations

- The right of receiving payment in conformity Keith the agreement on the condition and the exchange value of goods and/or services traded;

- The right of obtaining legal protection from the acts taken by consumers without a good intention;

- The right of making a proper self defense in the legal settlement of consumers' dispute;

- The right to the rehabilitation of reputation if it is legally proven that the losses sustained by consumers are not caused by the goods and/or services traded;

- The rights regulated in other laws.
- Having a good intention in conducting business activities;

- Providing correct, clear and honest information about the condition and guarantee of goods and/or services and providing explanation about uses, repair and maintenance;

- Treating or serving consumers correctly and honestly and indiscriminatority;

- Guaranteeing the quality of the goods and/or services produced and/or traded on the basis of the prevailing standard provisions on the quality of goods and/or services;

- Providing an opportunity to consumers to test and/or try certain goods and/or services and providing an assurance and/or a guarantee for the goods made and/or traded;

- Giving compensation and or refund for the losses caused by the use, application and utilization of goods and/or services traded;

- Giving compensation and/or refund if the goods and/or services received or utilized are not up to the agreement. 


\section{The Consumers}

\section{Rights}

Obligations

- The right to comfort, security and safety in using goods and/or services;

- The right of choosing goods and/ or services and obtaining the said goods and/or services in accordance with the exchange value and condition and guarantee pledged;

- The right to correct, clear and honest information about the condition and guarantee of the goods and/or services;

- The right that their opinions and complaints about goods and/or services used should be listened to;

- The right of obtaining advocacy, protection and an endeavor to properly settle disputes over consumers' protection;

- The right of obtaining consumers' fostering and education;

- The right of being correctly, honestly and indiscriminatory treated and served;

- The right of obtaining compensation and or refund if the goods and/or services received do not conform to the agreement or are not as they should be;

- The rights regulated in other laws.
- Reading or following information guidelines and procedure of using or utilizing goods and/or services for the sake of safety and security;

- Being well meaning in conducting transactions in the purchase of goods and/or services;

- Paying in conformity with the exchange value agreed;

- Following efforts to properly and legally settle disputes over consumers' protection.

According to the author, the efforts of consumer protection must have stages and broad coverage including protection of consumers before transactions, during transactions, and after transactions. Although this protection is intended for consumers, it does not mean that the interests of business actors do not get attention. Because after all, to 
create a fair and conducive business competition climate, the existence of business actors as producers or distributor of product goods and/or services must also get fair treatment by positioning them as partners of consumers in meeting the needs according to the rights and obligations arising from an engagement. The existence of equal legal protection for the parties is to realize the principle of justice so as to avoid the possibility of agreement default (wanprestasi) or acts violating the law that can harm one party. It is said wanprestasi if one of the parties does not carry out the obligations as agreed in the contract. Whereas it is said to be a violation of law when one party violates the regulations so that it harms the other party.

Consumer protection is a sharia obligation that is imposed on business actors, especially producers and distributors/sellers. Producers (al-muntaj) are people who produce goods and/or services needed by the consumer community to fulfill their life needs. Whereas the distributor (al-mażzu') is the party distributing the product until it reaches the hands of consumers both commercially engaged such as buying and selling as well as non-commercial products such as gifts. Both parties have legal responsibility for the products they distribute. The demands of product responsibility are basically justified if there are proven violations in the form of: (a) Unlawful violations committed by business actors; (b) Elements of losses experienced by consumers and; (c) The element of a causal relationship between elements of lawlessness and the element of loss. If the three elements are fulfilled, then the business actor has harmed the consumer so that he can be subject to legal sanctions or compensation payments.

\section{Consumer Protection of Islamic Perspective}

Consumer protection law has actually existed and set in the Qur'an before the country or the government draft law on consumer protection. ${ }^{13}$ In al-qur'ân, it is actually not mentioned lafadz or term of consumer

${ }^{13}$ Syaifullahil Maslul and Iyut Rizqi Utami, 'Halal Food Products Labeling According to Islamic Business Ethics and Consumers Protection Law', Al-Iktisab: Journal of Islamic Economic Law, 2.2 (2018) <https://doi.org/10.21111/al-iktisab.v2i2.3900>. 
(المستهلك). But the verses of al-qur'ân have explained many principles related to consumer protection. ${ }^{14}$ According to Ashfahnî, the term هلك has been stated in al-qur'ân through several meanings, namely: ${ }^{15}$

Table 1. The Term Consumer in the Qur'ân

\begin{tabular}{|c|c|c|}
\hline No & Meaning Context & Example of Ayat al-Qur'an \\
\hline 1 & Finish & $\begin{array}{l}\text { هل هلك عني سلطانية } \\
\text { The authority is finished from my hand (Q̈S. al- } \\
\text { Hāqqah [69]: 29). }\end{array}$ \\
\hline 2 & Damaging & $\begin{array}{l}\text { ويهلك الحرث والنيل } \\
\text { And damaging the crops and livestock (QS. al- } \\
\text { Baqarah [2]: 205) }\end{array}$ \\
\hline \multirow[t]{2}{*}{3} & Deaden & 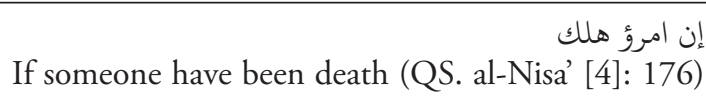 \\
\hline & & $\begin{array}{l}\text { وما يهلكنا إلا الدهر } \\
\text { Nothing will deaden us other than time (QS. al- } \\
\text { Jātsiyah [45]: 24) }\end{array}$ \\
\hline \multirow[t]{2}{*}{4} & Destruction & $\begin{array}{l}\text { Sل شيء هالك إلا وجه } \\
\text { Every thing will destruction, except Allah (QS. al- } \\
\text { Qashash [28]:88) }\end{array}$ \\
\hline & & $\begin{array}{l}\text { ولا تلقوا بأيديكم إلى التهلكة } \\
\text { And do not drop yourself into destruction (QS. } \\
\text { al-Baqarah [2]: 195) }\end{array}$ \\
\hline
\end{tabular}

Through these verses they allows us to say that the term consumer (المستهلك) is contained in al-qur'ân so that it can take lessons from it. Ashfahâî explains the meaning of الملاك which is identical to wearing or finishing, such as finishing the food. ${ }^{16}$ The meaning is very close to the use of the term fuqaha for the sentence ${ }^{17} 5$ الاستها which is trying to use/to consume. Therefore people who use or consume something (halâka al-sya'in) are referred to as consumers (al-mustahlak).

${ }^{14}$ Hamîd al-Shahîr, Ushül Himâyah Al-Mustahlak Fî al-Fiqh al-Islâmî Wa Aliyâtihâ (Alukah, 2015), p. 4.

${ }^{15}$ Râghib al-Ashfahânî, Al-Mufradât Fî̀ Gharîb al-Qur'ân (Riyadh: Maktabah Musthafâ Bâz, 2009), p. 708.

${ }^{16}$ Hamîd al-Shahîr, Ushūl Himâyah Al-Mustahlak Fî al-Fiqh al-Islâmî Wa Aliyâtihhâ, p. 5.

${ }^{17}$ Râghib al-Ashfahânî, Al-Mufradât Fî̀ Gharîb al-Qur'ân, p. 538. 
The meaning of something (al-syaiin) here means the product of goods and/or services produced by the producer. A product that has been used by consumers will inevitably decrease etiher in quantity or the quality will even be completely exhausted.

In the Islamic perspective, the provisions of halâl harâm are the right of Allah which is manifested through the practice of His Shari'a (al-qur'ân and al-sunnah). Al-qur'ân explained the meaning of consumers with the command sentence to consume something that is halâl and thayyib (QS. al-Baqarah [2]: 195) (QS. al-Māidah [5]: 88). Halâl is a skill from Allah SWT which is intended for His servants. Whereas the meaning of thayib is the benefit of the goodness of a substance from Allah so that it is used to fulfill physical needs (akhlâqiyah) and spirituality for His servants. Thayib is all objects which are characterized by good quality and cleanliness so that it is inversely proportional to ugliness and defilement (al-khabâis). All objects that are halâl and their legal status can be used syar'i. On the contrary, all objects that are khabâis is harâm. In al-qur'ân the spheres of thayyibât meaning has been explained, namely:

Table 2. Thayyibât Meaning in The Qur'ân ${ }^{18}$

\begin{tabular}{|c|c|c|}
\hline No & Scope of Thayyibât & Qur'ânic Verses \\
\hline 1 & $\begin{array}{l}\text { Thayyib for eaten and } \\
\text { drunk }\end{array}$ & 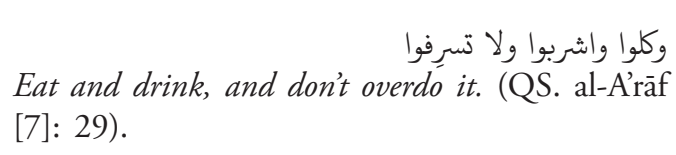 \\
\hline \multirow[t]{2}{*}{2} & $\begin{array}{l}\text { Thayyib in terms of } \\
\text { clothing }\end{array}$ & 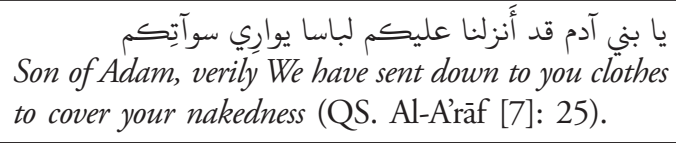 \\
\hline & & 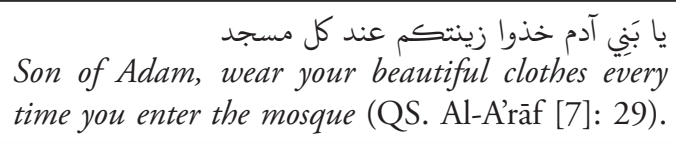 \\
\hline 3 & $\begin{array}{l}\text { Thayyib to be used as a } \\
\text { place to live }\end{array}$ & $\begin{array}{l}\text { And God made houses for you as a place to live } \\
\text { (QS. al-Nahl [16]: 80) }\end{array}$ \\
\hline
\end{tabular}

${ }^{18}$ Râghib al-Ashfahânî, p. 9-11 


\begin{tabular}{|c|c|c|}
\hline No & Scope of Thayyibât & Qur'ânic Verses \\
\hline \multirow[t]{2}{*}{4} & Thayyib for drive & $\begin{array}{l}\text { Horses, mules and donkeys for you to ride (QS. } \\
\text { al-Nahl [16]: 8) }\end{array}$ \\
\hline & & 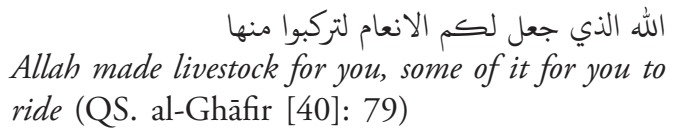 \\
\hline
\end{tabular}

Consumers will determine the choice to buy or not to buy depending on the level of benefit (maslahat) provided by a product and the price offered. Through the existence of products and prices offered by business actors, it allows consumers to meet their needs. On the contrary, through the existence of products and the pricing, a business actor can harm consumers. To determine the level of use of the product can be seen from two aspects, namely the level of halâlness and quality ( thayyiban). By consuming quality and quality products (goods and/or services) (thayyibatt), a consumer will get direct benefits from the use of those products, in the form of fulfilling the need to live a life so that he can worship Allah SWT. The amount of product benefits obtained is directly related to the frequency of consumption activities carried out. By consuming products that are halâl and thayyib means, the consumers have been practicing the commands of religion as stated in the word of God:

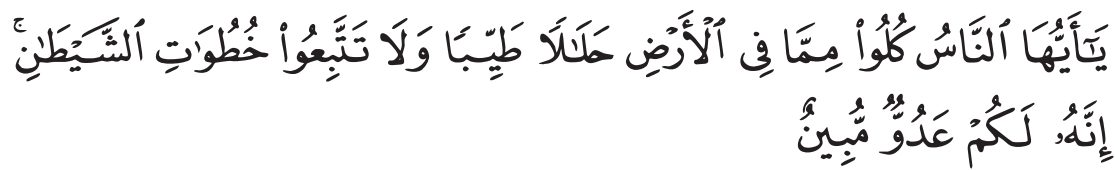

$O$ people eat from anything that is lawful (halal) and good (thayyib) from within the earth and do not follow the steps of devil, because in fact devil is the enemy who is for you (QS. al-Baqarah [2]: 168).

Allah SWT allows for humans to eat everything that is halâl and thayyib from the earth, that is everything that brings goodness and does not harm the body and mind, and forbids humans to follow the steps of devil, which are misleading like the jahiliyah people who forbid that is something justify ( $\underline{\text { a }}$ lâl), or justifying something $\underline{\text { halal }}$ that is forbided (barâm). The principle of halâl harâm as stated in that verse is valid for all 
acts and objects. Although in theory between human actions and objects as anyting related to action are differences, but in practice both of these elements remain an inseparable entity. ${ }^{19}$ In Islamic law, the provisions of the halâl harâm are clear, but between both there are always vague things (musytabihât) so that most people do not know it, as stated in the hadith:

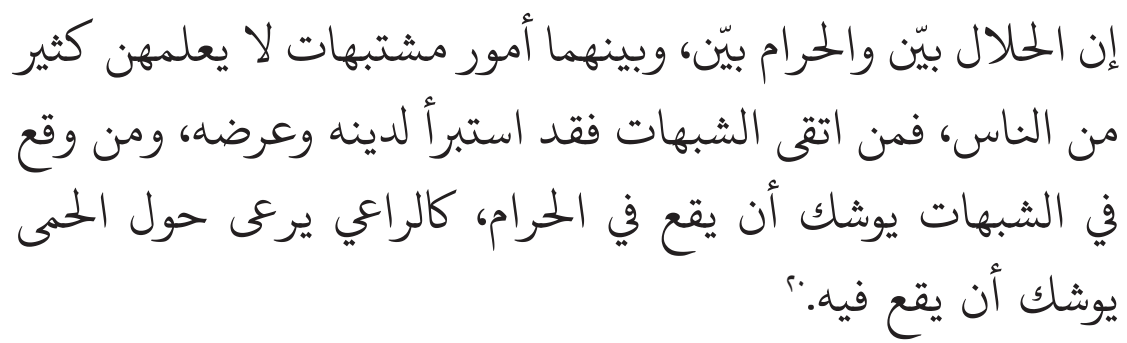

Indeed, the valid (halâl) is clear and the invalid (harâm) is clear. And between them there are cases of unclear (syubhat) which are unknown to most people. So whoever keeps from the shubhat has guarded his religion and honor. And whoever falls into the shubhat, he falls into things that are unclean.

The cleric (ulama) have agreed on the virtue of the hadith and the many benefits from it. The virtue of the hadith is that the Messenger of Allah has explained the importance of repairing food, drinks, clothing, etc. and the importance of leaving syubhat matters to protect the religion of a Muslim. ${ }^{21}$ Therefore, whoever leaves the matter of syubhât means to carry out religious advice, and vice versa, whoever does a syubhât case means that he has overrided religious advice. For business actors, syubhat cases can be avoided when carrying out the production or distribution process. As for consumers, syubhât cases can be avoided by the complate information of the products they will consume. Therefore according to Geraint, the complate information is available for consumers to protect themselves from the product which is not quality. ${ }^{22}$

${ }^{19}$ Rahmad Syafei, Fiqh Muamalah (Bandung: Pustaka Setia, 2004), p. 17.

${ }^{20}$ Imam Muslim, Shahîh Muslim, Juz 3 (Beirut: Dâr al-Kitab al-Ilmiyah, 2006), p. 1219.

${ }^{21}$ Hamâdi al-Jau'ânî, Dhawâbit Al-Tijârati Fî al-Iqtihâdi al-Islâmî (Beirut: Darul Kitab al-'Ilmiyah, 2005), p. 184.

${ }^{22}$ The importance of information in empowering consumers is be concluded from opinion Geraint Howells, 'The Potential and Limits of Consumer Empowerment by Information', Journal of Law and Society, 32.3 (2005), 349-70 <https://doi.org/10.1111/j.1467-6478.2005.00328.x>. 
A good business actors is a business agent who runs their business legally (al-tijârî al-syarî̀) so as to provide benefits for himself and for other parties as his business partners. The benefit of a business actor who is syar' $\hat{\imath}$ is in the form of blessing of tresure (al-rizk al-mubârak) in the world and all his efforts will later be recorded as pious deeds (alamal al-shâlih) in the hereafter. Likewise, vice versa, business actors who run their businesses in a illegal (dzalim) manner, mean they have lost themselves and others. Losses of business actor who do business illegally are revocation of life's blessings in the world, while in the hereafter are in the form of punishment. As for the other parties to be harmed, there are two possibilities, namely business competitors and/or consumers. Among business actors it can be mutually harmful to each other in the event of unfair business competition. In fact, due to unfair business competition often has an impact on consumer losses. The meaning of loss here must be understood broadly, which includes the loss in the world and the hereafter (khusira al-dunyâ wa al-akhirah) (QS. al-Hajj [22]: 11$)^{23}$ before then being described in more detail.

Consumer protection efforts can only be maximally implemented if all potential losses can be well known. The potential loss inherent in the consumer due to the use of goods and/or services can be divided into: (1) Material losses (al-khasârah al-mâdiyah) namely in the form of financial assets (al-khasârah al-mâdiyah al-mâliyah) and non-financial (alkhasârah al-mâdiyah ghairu al-mâliyah); (2) Human damages (al-khasârah al-insâniyah), namely both physical (al-khasârah al-insâniyah al-jasadiyah) such as physical illness or even death due to consumption of products, and there are human spiritual losses (al-khasârah al-insâniyah al-rühiyah) such as damage to human beliefs, thoughts, behavior/morals. The overall potential loss of consumers needs to be accommodated in an integrated legislation to better guarantee legal certainty.

${ }^{23}$ The context of that verse is related to the doubtful nature of a person in religion so that it tends to be pragmatic and easy to override the provisions of the Shari'a only to gain worldly benefits. Ibnu Katsir, Tafsîr Al-Qur'ân al-Adhîm, Jilid V (Riyadh: ar Thayyibah, 1997), p. 400. 
Table 3. The Scope of Consumer Potential Losses

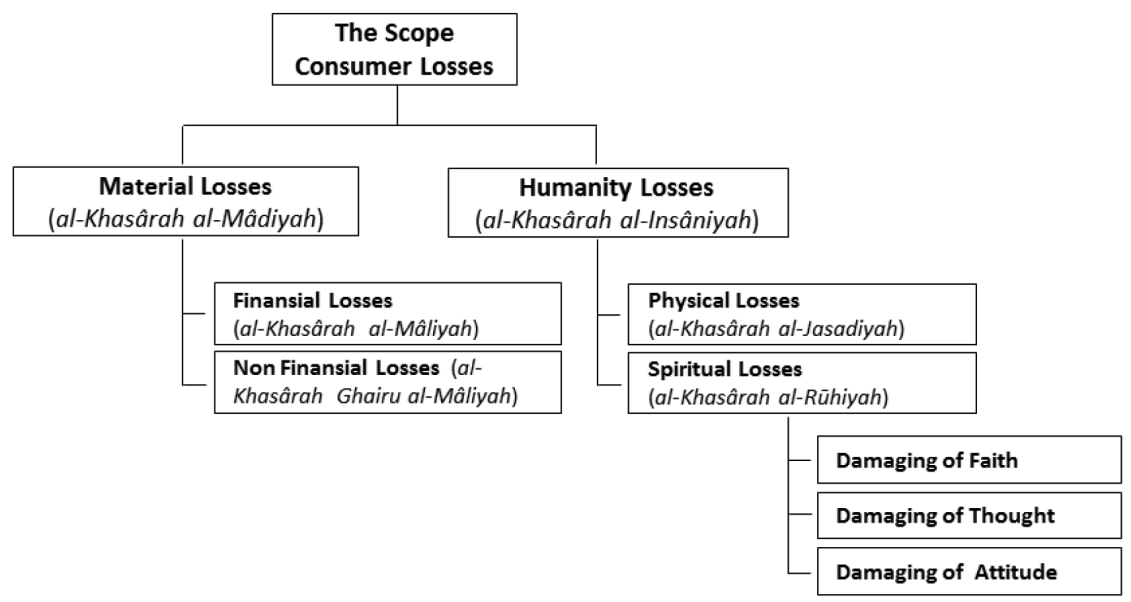

The legal concept of consumer protection in the Islamic perspective can be implemented through two approachs which are started from preventive and repressive efforts. Consumer protection through prevention, namely protection of consumers to avoid deviating act of bussiness actors that harm consumers. Those who discuss deviant actions here are for reasons breaking of contract (wanprestasi) and/or act violating to the law. Evoidance efforts of consumer protection can be implemented started from the production process of goods and/or services to distribution to consumers. In addition, prevention efforts can also be done through the proper implementation of the Islamic contract. According to Khan, the general principles of Islamic contracts $(a l-\dot{u} q \hat{u} d)$ are presented with special reference to the protection of consumers. They have also provided a number of options to give chance to a consumer who suffered some loss in transaction to revoke contract within stipulated time. They have been designed to maintain balance in transactions and to protect a weaker party from being harmed. ${ }^{24}$ While consumer protection that represents repressiveness is the protection of consumers through law enforcement due to deviant actions, namely the imposition of penalties both related to administrative, civil, and even punishment.

${ }^{24}$ Muhammad Akbar Khan, Consumer Protection and the Islamic Law of Contract (Rochester, NY: Social Science Research Network, 19 November 2011) <https://papers.ssrn. com/abstract $=1961912>$. 
Table 4. The Phasing of Consumer Protection

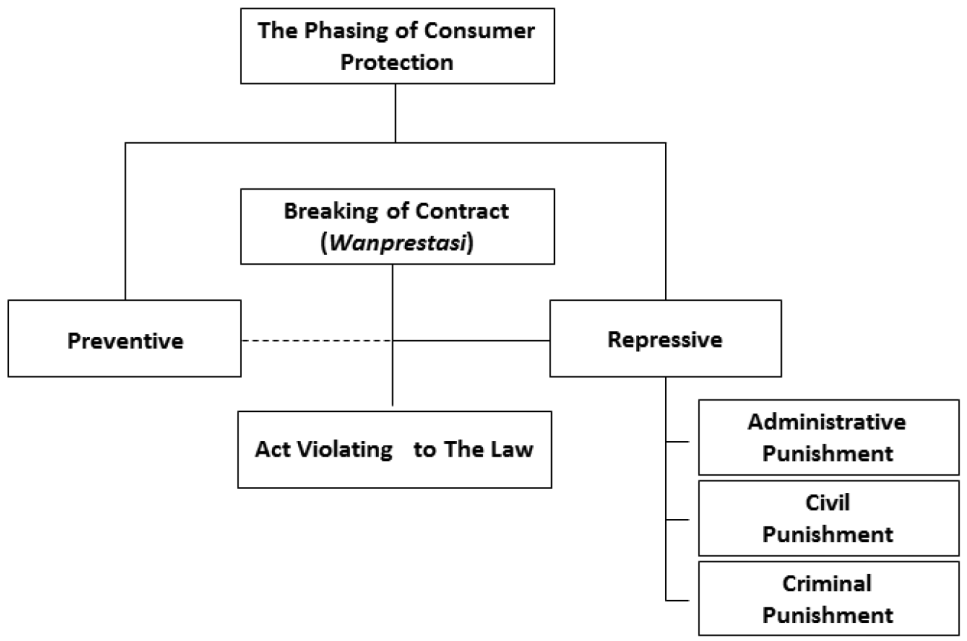

The scope of consumer protection through preventive and repressive efforts can be implemented before a transaction, at the time of the transaction, until after the transaction. Before transactions, consumer protection can be sought through fostering awareness for business actors when they run their business. The meaning of business actors are producers who produce goods and/or services before being marketed by distributors/ sellers to consumers. It mean that producers are required to produce goods and/or services that are halâl and quality so provide maximum benefit for its users. Besides producers, preventive consumer protection efforts can also be implemented by distributors/sellers, especially when conducting transactions until after the transaction.

The term production (al-intâj) in language means producing something continuously. According to the Islamic scholar (fuqaha), ${ }^{25}$ the meaning of production is synonymous with effort (al-kasb) which is seeking rizki (طلب الرزق). natural resources to realize people's welfare. ${ }^{27}$ Islam has given awards

${ }^{25}$ Sayyid Ahmad, Himâyat Al-Mustahlak Fî al-Fiqh al-Islâmî (Beirut: Darul Kitabah alIlmiyah, 2003), p. 45.

${ }^{26}$ Sayyid Ahmad, Himâyat, p. 46

${ }^{27}$ Abdul Muhsin al-Tharîqî, Al-Irtishâd al-Islâmî: Ususun Wa Mabâdì Wa Ahdâf, (Riyadh: 
related to production because it is so important for the continuity of resources to strengthen and fulfill the needs of the people. ${ }^{28}$ Therefore the purpose of production in Islam is very noble, namely to prosper the earth and to realize the welfare of society in order to obey Allah. ${ }^{29}$ To be able to carry out the production process, there are three main elements that must be met, namely: (1) Availability of human resources (al-mawârid al-insâni); (2) Use of natural resources (al-istifâdat min almawârid al-thabîiyati); (3) Capital (ra'su al-mâl). ${ }^{30}$ Producers who protect consumers are producers who are able to guarantee halâl and quality (balâlan thayyiban) products of goods and/or services as well as price offerings that are appropriate so can provide benefits to consumers.

Table 5. Suitability of Product and Pricing

\begin{tabular}{cccc}
\hline Criteria & $\begin{array}{c}\text { Halâl and } \\
\text { Quality }\end{array}$ & $\begin{array}{c}\text { Halâl But Not } \\
\text { Quaity }\end{array}$ & $\begin{array}{c}\text { Harâm or Not } \\
\text { Quality }\end{array}$ \\
\hline Appropriate Price & $(1)$ & $(2)$ & $(3)$ \\
\hline Inappropriate Price & $(4)$ & $(5)$ & $(6)$ \\
\hline
\end{tabular}

Based on the matrix above, it means that the business actor when producing and offering prices of goods and/or services there are four possibilities that occur, namely (1) Producing $\underline{h}$ alâl and quality of products with an appropriate price offering; (2) Producing halâl of products but have not quality even though the price is appropriate. Halal products whic are non-quality still have the potential to harm consumers even though the price is appropriate; (3) Producing harâm of products and have not quality at appropriate prices. It must be understood that all harâm products of course have no quality so they must harm consumers; (4) Producing halal and quality of products but with an inappropriate price offering. Inappropriate price offering must harm consumers; (5) Producing halâl products but not quality with an inappropriate price offering; and (6)

Jâmi'atul Maliki, 2009), p. 76.

${ }^{28}$ Abdul Muhsin al-Tharîqî, Al-Irtishâd, p. 76

${ }^{29}$ Sayyid Ahmad, Himâyat al-Mustahlak fî al-Figh al-Islâmî, p. 47

${ }^{30}$ Abdul Muhsin al-Tharîqî, Al-Irtishâd al-Islâmî: Ususun wa Mabâdì wa Ahdâf, p. 81-84 
Producing harâm products and have not quality with an inappropriate price offering. From the six possibilities, the first point is the choice of the most appropriate for business actors to realize consumer protection.

Table 6. The Impact of Level Suitability of Product and Price For Consumers

\begin{tabular}{|c|c|c|c|}
\hline \multirow{2}{*}{ No } & \multirow{2}{*}{$\begin{array}{c}\text { Probability in Production and } \\
\text { Distribution }\end{array}$} & \multicolumn{2}{|c|}{ The Impact For Consumers } \\
\hline & & $(+)$ & $(-)$ \\
\hline 1 & $\begin{array}{l}\text { Producing } \underline{\text { halal } \text { and quality of products with }} \\
\text { an appropriate price offering }\end{array}$ & $\sqrt{ }$ & - \\
\hline 2 & $\begin{array}{l}\text { Producing } \underline{h} \text { alal of products but have not } \\
\text { quality even though the price is appropriate. }\end{array}$ & - & $\sqrt{ }$ \\
\hline 3 & $\begin{array}{l}\text { Producing } \underline{\text { harâm }} \text { of products and have not } \\
\text { quality at appropriate prices. }\end{array}$ & - & $\sqrt{ }$ \\
\hline 4 & 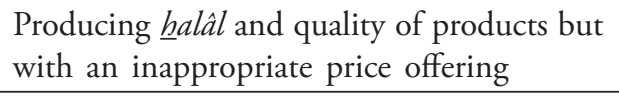 & - & $\sqrt{ }$ \\
\hline 5 & $\begin{array}{l}\text { Producing } \underline{\text { halâl }} \text { products but not quality } \\
\text { with an inappropriate price offering }\end{array}$ & - & $\sqrt{ }$ \\
\hline 6 & $\begin{array}{l}\text { Producing harâm products and have not } \\
\text { quality with an inappropriate price offering. }\end{array}$ & - & $\sqrt{ }$ \\
\hline
\end{tabular}

Halâl products but have not quality with appropriate price offering is still have the potential to harm consumers. If the consumption is in the form benefits of goods, so the consumer loss is that goods will be easily damaged, whereas if the consumption is in the form of food/drink, so the consumer loss is from the health aspect. The advantages of halal products that are have not quality are the prices relatively cheaper so that they are affordable for certain economic classes. But if the price is not in accordance with the product, then consumers will also be harmed by its financial aspects. All products that are $\underline{h} a r a ̂ m$ are definitely have no quality so that must harm consumers. The loss of consumers who consume harâm products or have no quality is that they can damage their health and damage their mental spirituality. Even if the price is not appropriate with the reality of the product, consumers will suffer financial losses as well.

Consumer protection at the time of the transaction can be realized through the implementation of contracts between business actors 
(distributors/sellers) with consumers. In the Islamic concept, the number of contracts underlying the transaction is diverse, so that its use must be adjusted to the intent of the contract itself. To realize consumer protection, the main step that must be taken by business actors is implementing the contract legally. The contract is said to be valid if the conditions attached to the pillars of the contract are fulfilled, such as the conditions attached to the parties (âqidaini), the object of the contract ( $m a$ 'qū 'alayh), and agreement (ijâb qabūl). Of the three pillars that are most related to consumer protection efforts are the fulfillment of the conditions attached to the object of the contract. The terms of the contract object are: (1) Something that is the object of the contract must be in accordance with sharia principles (masyrū '); (2) The clarity of the contract object so that it can be handed over; (3) The existence of perfect ownership of the contract object. ${ }^{31}$

In general, a contract is the result of agreement between both parties where each of party have equality of opportunity for bargaining. But need to know that there are exceptions to certain clauses that have been standardized, in such a way that one party cannot make a bargaining. An agreement that has been standardized by one party so that the other party cannot bargain known as the standard contract ('aqd al-iz'ân). ${ }^{32}$ The standard contract is a new phenomenon in modern life, so it has not been found at the time of the Prophet Muhammad. ${ }^{33}$ However, in Islamic law there are a number of rules that emphasize the principle of justice and benefit between the two parties. Therefore the standard contract according to author is permissible as long as it not contrary to the both principles and not harm to one of the parties. To achieve this purpose, then in sharia contract law always requires the parties to prioritize the will of the sharia when they will make draft of a standard contract. By relying on the will of the sharia, means that what is expected

${ }^{31}$ Syamsul Anwar, Hukum Perjanjian Syariah (Studi Tentang Teori Akad dalam Fiqh Muamalat (Jakarta: Rajawali Pers, 2007), p. 191.

32 Burhanuddin S, Hukum Kontrak Syariah, Cet Ke-1 (Yogyakarta: BPFE UGM, 2009), p. 42.

${ }^{33}$ Syamsul Anwar, Hukum Perjanjian Syariah (Studi Tentang Teori Akad dalam Fiqh Muamalat), p. 319. 
by one of the parties, of course, will be hopeful for the other party. ${ }^{34}$ This means that even though the contract contains a standard clause, but the rights and obligations between the business actor and the consumer remain accommodated proportionally.

Consumer protection after the transaction is realized in various forms, namely: (1) Enforcement of the right of khiyâr, namely the right granted by the parties to continue or cancel the contract. ${ }^{35}$ The right of khiyâr can be given to consumers to cancel the contract with the following conditions: (a) The parties are still in the place of the contract (khiyâr majlis); (b) There are requirements for khiyâr up to a certain time according to the agreement (khiyâr syarath); (c) There is damage to the transaction object (khiyâr 'aib); (d) There is a discrepancy between the object ordered and the one received/seen (khiyär rukyah); (d) There is a discrepancy between the object of the transaction and the price paid (khiyâr nuqud). (2) Enforcement of the principle of iqâlah, namely the right granted to the buyer to cancel the contract that is already binding after obtaining approval from the seller. (3) Including forms of consumer protection after a transaction is the giving of the right to consumers to get compensation (ta'wid).

Table 7. The Implementation of Consumer Protection

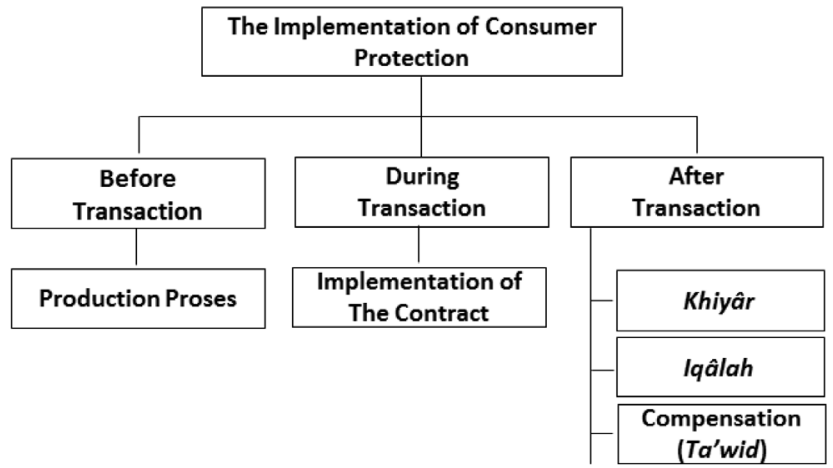

${ }^{34}$ Burhanuddin S, Hukum Kontrak Syariah, p. 42

${ }^{35}$ Khiyâr is derived from word ihtiyâr that means determining the best choice of two affairs (طلب خير الأمرين) namely for continue or deleting of transaction. See Mahmudin Ahmad al-'Aini, Umdat Al-Qârî: Syarh Shahîh al-Muhtârî (Beirut: Darul Kitab al-Ilmiyah), p. 321. 
Customer protection in Islam is embedded in the responsibility to care for the relationship between humans (hablu min al-nās) which is considered as a manifestation of each person's belief in Allah and the existence of the Hereafter where each person will be held accountable for their acts. ${ }^{36}$ Islamic law has prescribed physical as well as moral sanctions for harming the consumer interests along with fines as punishment for the violation of consumer rights. In Islamic law a wrongdoer is punished not only in this world but also in the hereafter for the violation of moral duties. Therefore, it is more effective to protect consumer rights in Muslims jurisdictions provided the laws are in accordance with their faith. ${ }^{37}$ The concept of consumer protection mentioned above is the result of the development of science through the Islamic law perspective in order to reconstruct before concepts which tend not to touch aspects of the divine values.

\section{Conclusion}

Consumers use a product of goods and/or services aimed at fulfilling their daily needs. Good products are products which are legal (balâl) and have quality (thayyib) with appropriate pricing so provide maximum benefit for users. The concept of consumer protection law under Islamic perspective can be implemented through two approaches both preventive and repressive efforts. Preventive consumer protection, namely consumer protection through efforts to prevent deviant actions during the production process (before transactions) to distribution (during transactions) of goods and/or services to consumers. The protection of consumers after transactions can be realized in the form of the application of the principle of khiyâr, iqâlah and compensation (ta'wìd). While repressive consumer protection is the protection of consumers through the imposition of sanctions due to breaking of contract (wanprestasi) or action violating the law which has an impact on consumer losses. The consumer protection law can only be maximally implemented if all potential losses can be

\footnotetext{
${ }^{36}$ Hamidah Atob, 'Consumer Protection In Islam: An Overview', p. 2.

${ }^{37}$ Muhammad Akbar Khan, "Consumer Protection in Islamic Law (Shariah): An Overview,"' Al-Adwa, 45, p. 93.
} 
well known. The potential loss inherent in the consumer due to the use of goods and/or services can be divided into: (1) Material losses (alkhasârah al-mâdiyah) namely in the form of financial assets (al-khasârah al-mâdiyah al-mâliyah) and non-financial (al-khasârah al-mâdiyah ghairu al-mâliyah); (2) Human damages (al-khasârah al-insâniyah), namely both physical (al-khasârah al-insâniyah al-jasadiyah) such as physical illness or even death due to consumption of products, and there are spiritual loss (al-khasrah al-insâniyah al-rühiyah) such as damage to human beliefs, thoughts, behavior/morals. The overall potential for consumer losses in concept of Islamic law needs to be accommodated in an integrated regulation so it will be more guarantee legal certainty for consumers.

\section{Bibliography}

Ahmad al-'Aini, Mahmudin, Umdat Al-Qârî: Syarh Shahîh al-Muhtârî. Beirut: Darul Kitab al-Ilmiyah.

Ahmad, Sayyid, Himâyat Al-Mustahlak Fî al-Fiqh al-Islâmî. Beirut: Darul Kitabah al-Ilmiyah, 2003.

Akbar Khan, Muhammad, "Consumer Protection in Islamic Law (Shariah): An Overview,' Al-Adwa, 45.

Anwar, Syamsul, Hukum Perjanjian Syariah (Studi Tentang Teori Akad dalam Figh Muamalat. Jakarta: Rajawali Pers, 2007.

Ashfahânî, Râghib al-, al-Mufradât Fî̀ Gharîb al-Qur'ân. Riyadh: Maktabah Musthafâ Bâz, 2009.

Atob, Hamidah, 'Consumer Protection In Islam: An Overview'

Az. Nasution, Hukum Perlindungan Konsumen. Jakarta: Dayawidya, 1999.

Burhanuddin S, Hukum Kontrak Syariah, Cet Ke-1. Yogyakarta: BPFE UGM, 2009.

- Pemikiran Hukum Perlindungan Konsumen dan Sertifikasi Halal. Malang: UIN Maliki Press, 2011.

Howells, Geraint, 'The Potential and Limits of Consumer Empowerment by Information', Journal of Law and Society, 32.3 (2005), 349-70 <https://doi.org/10.1111/j.1467-6478.2005.00328.x>

Ibnu Katsir, Tafsîr Al-Qur'ân al-Adhîm, Jilid V. Riyadh: ar Thayyibah, 1997. 
Jau'ânî, Hamâdi al-. Dhawâbit Al-Tijârati Fî̀ al-Iqtihâdi al-Islâmî. Beirut: Darul Kitab al-'Ilmiyah, 2005.

Khan, Muhammad Akbar, Consumer Protection and the Islamic Law of Contract. Rochester, NY: Social Science Research Network, 19 November 2011.<https://papers.ssrn.com/abstract=1961912>.

Maslul, Syaifullahil, and Iyut Rizqi Utami, 'Halal Food Products Labeling According to Islamic Business Ethics and Consumers Protection Law', Al-Iktisab: Journal of Islamic Economic Law, 2.2 (2018) <https://doi. org/10.21111/al-iktisab.v2i2.3900>

Mancuso, S., 'Consumer Protection in E-Commerce Transaction: A First Comparasion Between European Law and Islamic Law', Journal of International Commercial Law and Technology, 2 (2007), 1.

Muslim, Imam, Shahîh Muslim, Juz 3. Beirut: Dâr al-Kitab al-Ilmiyah, 2006. Resolution of the UN General Assembly, Number A/RES/39/248 Year 1985 Concerning Guidelines for Consumers Protection.

Roestamy, Martin, 'Consumer Protection of Halal Meat under Islamic Law and Indonesian Regulation', Journal of Law, Policy and Globalization, 35.0 (2015), 88-94-94.

Rosadi, Sinta Dewi, and Zahra Tahira, 'Consumer Protection In Digital Economy Era : Law In Indonesia', Yustisia Jurnal Hukum, 7.1 (2018), 85-97. <https://doi.org/10.20961/yustisia.v0i0.20144>

Shahîr, Hamîd al-, Ushūl Himâyah Al-Mustahlak Fî al-Figh al-Islâmî Wa Aliyâtihâ. Alukah, 2015.

Syafei, Rahmad, Fiqh Muamalah. Bandung: Pustaka Setia, 2004.

Shidarta, Hukum Perlindungan Konsumen. Jakarta: Grasindo, 2000. , and Stefan Koos, 'Introduction To A Social-Functional Approach In The Indonesian Consumer Protection Law', Veritas et Justitia, 5.1 (2019), 49-79. <https://doi.org/10.25123/vej.3292>

Tharîqî, Abdul Muhsin al-. Al-Irtishâd al-Islâmî: Ususun Wa Mabâdi' Wa Ahdâf. Riyadh: Jâmi’atul Maliki, 2009.

Wiryani, 'Juridical Analysis On Consumer Protection In Safe and Halal Food Distribution, Jurnal Dinamika Hukum' . <http://dinamikahukum. fh.unsoed.ac.id/index.php/JDH/article/view/1586> 